\title{
Genital siğilli hastalarda cinsel yolla bulaşan diğer hastalıklara ait serolojik test sonuçları: Retrospektif bir değerlendirme
}

\section{Serological profile of other sexually transmitted diseases in patients with condyloma acuminata: A retrospective view}

\section{Habibullah Aktaş ${ }^{1}$, Gökşen Ertuğrul ${ }^{1}$, Ali Ramazan Benli ${ }^{2}$}

\section{$\ddot{\mathrm{Oz}}$}

Amaç: Bu çalışmada, genital siğil tanısı almış hastalarda cinsel yolla bulaşan diğer hastalıklara ait serolojik tes sonuçlarının değerlendirilmesi hedeflenmiş̦tir.

Yöntemler: Şubat 2015 ile Temmuz 2016 arasında dermatoloji polikliniğinde genital siğil tanısı alan 74' ü erkek 35' i kadın 109 hastanın dosya kayıtları taranarak, cinsel yolla bulaşan diğer hastalıklara ait veriler elde edildi. Sonuçlar demografik olarak değerlendirildi.

Bulgular: Sonuçları elde edilen 109 hastanın 74'ü erkek 35'i bayandı. Yaş ortalaması 33,7 yıl bulundu. Hiçbir hastada HIV ve VDRL testi pozitif bulunmazken, bir erkek hastada HBsAg, bir kadın hastada da anti-HCV testi pozitif saptandı. 28 hastada anti-HBs pozitif idi. Kadın hastaların sadece \% 17,6 s1 40 yaş üzerinde iken, erkek hastalarda bu oran $\% 36,4$ ile daha yüksek bulundu.

Sonuç: Genital siğillerin cinsel yolla bulaşan diğer hastalıkların görülme sıklığını da artırması beklenirken, bulunan oranlar genital siğilin hepatit $\mathrm{B}$, hepatit $\mathrm{C}$, edinsel immün yetmezlik sendromu, sifiliz gibi diğer hastalıkların görülme sıklığını değiştirmediğini gösterdi. Uzun izlemli, daha genişs sayıda taramalar daha sağlıkl çıkarımlar sağlayacaktır.

Anahtar Kelimeler: Genital siğil, Seroloji, Cinsel yolla bulaşan hastalıklar

\section{Abstract}

Aim: In this study, we aimed the possible coexistence of other sexullay transmitted diseases with condyloma acuminata patients.

Methods: The files of 109 condyloma acuminata patients admitted between February 2015 and July 2016 were searched retrospectively. Their serological test results were noted according to their demographic properties.

Results: Of 109 patients whose results obtained, 74 were male and 35 were female patients. Average age of the patients was 33.7 years. There was no positive case of VDRL and anti-HIV, however, HBsAg positivity in a male patient and anti-HCV positivity in a female patient were detected. A total of 28 patients was found to have anti-HBs positivity. While only $17.6 \%$ of the female patients were over 40 years old, that number was significantly higher as $36.4 \%$ in male patients with condyloma acuminata.

Conclusion: Although there is a prediction that condyloma acuminata patients have more incidence of other sexually transmitted diseases, this small retrospective study shows no more coexistence between condyloma acuminata and other sexually transmitted diseases. However, further studies with high number of patients and long-term follow up will provide better conclusions.

Keywords: Condyloma acuminata, Serology, Sexually transmitted diseases

\section{Giriş}

Genital siğil, insan papilloma virüsü (HPV)'nün neden olduğu, genellikle cinsel yolla bulaşan genital yerleşimli bir deri hastalığıdır. Genital verruka ya da kondiloma akuminata adlarıyla da bilinir. Hastalığı bulaştıran HPV'nin onkojen bir karakter taşıması nedeniyle halk sağlığ 1 açısından önemi büyüktür. Kadın genital neoplazileri arasında çok sık rastlanılan serviks kanserinin, erkeklerde ise penis kanserinin en önemli etkeni HPV'dir [1]. Genital siğilin bir başka önemi HPV taşıyıcısı hastanın potansiyel olarak cinsel yolla bulaşan insan immün yetmezlik virüsü (HIV), hepatit $\mathrm{B}$, hepatit $\mathrm{C}$ ve sifiliz gibi diğer hastalıklara da maruz kalabileceğidir.

$\mathrm{Bu}$ çalışmada genital siğil tespit edilen hastalarda cinsel yolla bulaşan diğer hastalıkların varlığı araştırıldı.
1 Karabük Eğitim ve Araştırma Hastanesi Dermatoloji Kliniği.

${ }^{2}$ Karabük Eğitim ve Araştırma Hastanesi,Aile Hekimliği

Etik Kurul: Çalışmanın retrospektif dizaynından dolayı etik kurul onayı alınmamıştır.

Ethical approval: Due to retrospective design of the study, no ethical approval has been taken.

Çıkar Çatışması: Yazarlar herhangi bir çıkar çatışması bildirmemişlerdir.

Conflict of Interest: No conflict of interest was declared by the authors

Finansal Destek: Yazarlar bu olgu için finansal destek almadıklarını beyan etmislerdir.

Financial Disclosure: The authors declared that this case has received no financial support.

Geliș Tarihi / Received

09.03.2017

Kabul Tarihi / Accepted 02.04.2017

Yayın Tarihi / Published

17.04 .2017

Sorumlu yazar / Corresponding author

Habibullah Aktaş

Adres: Karabük Eğitim ve Araștırma Hastanes Dermatoloji Kliniği. Bağlarbaşı mah.Akçaoğlu sok.7-6 Safranbolu, Karabük, Türkiye

Tel: +90532 4084611

E-posta: aktashabib@hotmail.com

(c) Copyright 2017 ACEM 


\section{Gereç ve Yöntemler}

Şubat 2015 ile Temmuz 2016 arasında Karabük Eğitim ve Araştırma Hastanesi Dermatoloji polikliniğine başvuran ve genital siğil teşhisi alan hastalar retrospektif olarak tarandı. Çalışma süresince Helsinki bildirgesine uygun olarak hasta mahremiyetine özen gösterildi. Retrospektif çalışma tipinden dolayı Etik Kurul onamı ve yazılı hasta onamı alınmadı.

Hastaların demografik verileri (yaş ve cinsiyet) yanında, hepatit B yüzey antijeni (HbsAg), anti-HBs antikoru (anti-HBs), anti-hepatit $\mathrm{C}$ virüs antikoru (anti-HCV), anti-HIV antikoru ve VDRL (Venereal Disease Research Laboratory) testleri incelendi. Yaş ve cinsiyetlerine göre tarama sonuçları değerlendirildi. Tanımlayıcı istatistikler frekans ve yüzde olarak belirtildi.

\section{Bulgular}

Verilen tarihler arasında 109 genital siğil tanılı hastanın sonuçları elde edildi. Yaş ortalaması 33,7 yıl olarak saptanan hastaların 74 'ü erkek $(\% 67,8)$ ve 35 (\%32,2)'i kadın hastaydı.2065 yaş arasındaki 74 erkek hastanın yaş ortalaması $35,2 \pm 7,2$ yıl ve 17-58 yaşları arasındaki 35 kadın hastanın yaş ortalaması $30,5 \pm 6,8$ yıl olarak bulundu. Kadın hastalarda 40 yaşın üzerinde sadece altı hasta $(\% 17,6)$ varken, erkek hastalarda 40 yaş üzeri hasta say1s1 $27(\% 36,4)$ idi.

109 hastada $\mathrm{HBsAg}$, anti-HBs ve anti-HCV testlerine ulaş1lırken, 104 hastada $\mathrm{HBsAg}$, anti-HBs, anti-HCV ve antiHIV, 98 hastanın ise yukarıdakilere ek olarak VDRL testi sonuçları da elde edildi. Sekiz hastanın anti-HIV ve11 hastanın da VDRL test sonuçları elde edilemedi.

Anti-HIV (n=101) ve VDRL $(n=98)$ testlerinin sonuçları görülen hastaların tamamında negatif bulunurken, bir hastada $(\% 0,9)$ HBsAg pozitif, bir hastada da $(\% 0,9)$ anti-HCV pozitif olarak saptand1. Toplam 28 hastada $(\% 25,6)$ anti-HBs pozitifliği saptandı. Anti-HBs saptanan hastaların 21'i erkek $(\% 28,3)$ ve yedisi kadın ( \%20) idi. Anti-HBs pozitifliği saptanan yedi kadın hastanın yaş ortalaması 24,4 $\pm 5,4$ yıl (yaş aralığı 21-44 yıl), erkek hastaların ise 31,7 $\pm 5,1$ yıl (yaş aralığ $20-60$ yıl) idi.

\section{Tartışma}

Genital siğiller şehirleşmiş toplumlarda insanlar arası iletişimin artmasına paralel olarak, kırsal alanlara göre daha sık rastlanan bir sağlık sorunudur. Hastalığın nedeni olan HPV'nin onkojenik özellik taşıması ve ölümcül seyredebilen neoplastik hastalıklara da yol açabilmesi nedeniyle, genital siğiller halk sağlığı açısından önemsenmesi gereken bir sorundur [1]. Bulaş kaynağının aynı zamanda HIV, hepatit $\mathrm{B}$, hepatit $\mathrm{C}$ ve sifiliz gibi diğer seksüel geçişli hastalıkların da taşıyıcısı olma potansiyeli nedeniyle, genital siğilin yanı sıra bu hastalıkları da bulaştırabilmesi muhtemeldir.

Literatürde genital siğilli hastalarda cinsel yolla bulaşan diğer hastalıkların araştırıldığı az sayıda makale vardır. $\mathrm{Bu}$ konuda en kapsamlı çalışmalardan biri Ünal ve arkadaşlarının 94 hastada yaptı̆̆ı seroprevalans çalışmasıdır [2]. Bu çalışmada hastaların \%88'i erkek, \%12'si kadın iken, bizim hastalarımızda kadın hasta oranı \%32 gibi bu çalışmaya göre daha yüksek idi. Kadın/erkek oranı farkının tarama yapılan kliniklerin hasta portföyünün sosyokültürel farklılığına, daha çok kadın-doğum kliniğine başvurmasına ya da Ünal ve arkadaşlarının çalışmasının yapıldığı metropol özelliği olan bir kentte kadınların sosyal bir gerekçe olarak özel sağlık hizmetine daha çok yönlenmesine bağlanabilir. Yine aynı çalışmada ortalama yaş 34 yıl iken bizim hasta grubumuzun yaş ortalaması benzer şekilde 33,7 yıl olarak saptandı [2]. Kaymak ve arkadaşlarının yaptığı bir çalışmada, yaşları 18-71 yıl arasında değişen 50 hastanın 36'sı erkek (\%72) ve 14“ü (\%28) kadındı. Kadın-erkek oranının bizim çalışmamızdaki orana benzer olduğu tespit edildi. Hastaların yaş ortalaması 32,3 yıl ile literatür ile uyumlu idi [2, $3]$.

Taraması yapılan genital siğilli erkek hastalarımızın 40 yaş ve üzerinde olanları aynı yaş grubundaki kadın hastalardan daha fazla idi. Bu durum Ünal ve arkadaşlarının ve Kaymak ve arkadaşlarının çalışmalarında da belirtilmemiş olsa da, 40 yaş ve üzeri hastaların oransal olarak çoğunluğunun erkek olması birkaç görüşle açıklanabilir [2, 3]. Siğil tespit edilen 40 yaş üzeri kadın hastaların kadın doğum kliniklerine başvuruyor olması, yaşam konforunu çok bozmadığı düşünülerek küçük bir et parçasının hekime başvurulacak ölçüde önemli bulunmaması ya da 40 yaş üstü erkek hastaların eşleri dışında taşıyıcı cinsel partnerlerle birlikte olma olasılığıdır. Nitekim sıklıkla poliklinik hasta öykülerinde belli bir yaşın üstündeki erkek bireylerde hastalık belirtilerinin yasal ya da yasadışı ticari partnerle cinsel ilişki sonrası ortaya çıktığı öğrenilmektedir.

Ünal ve arkaadaşlarının çalışmasında anti-HCV ve antiHIV pozitifliğine rastlanılmamış iken, bizim çalışmamızda da anti-HIV pozitif vaka saptanmamış, sadece bir hastada anti-HCV pozitifliği gösterilmiştir (2).Yine aynı çalışmada 94 hastada üç VDRL-TPHA pozitifliği ile üç HBsAg pozitifliği tesbit edilirken, benzer sayıdaki sayıdaki hasta grubumuzda sadece bir hastada HbsAg pozitifliği saptandı. Bizim çalışmamızda VDRL pozitif bir hastaya rastlanılmamıştır. Benzer şekilde Kavak ve ark. 26 kondilom hastasında anti-HCV ve anti-HIV pozitifliği saptanmadı [4]. Kaymak ve arkadaşlarının [3] 50 hastalık çalışmasında 2 hastada sifiliz saptanırken, hiç bir hastada HBsAg,anti- HCV ve anti-HIV pozitifliği görülmemiştir. AntiHBs pozitifliği de sadece üç hastada saptanmıştır. Bizim çalışmamızda $28(\% 25,6)$ anti-HBs pozitif hasta saptanırken, Kaymak'ın çalışmasında sadece \%6'lık pozitiflik olması, bu çalışmanın 2004 yılında yapılmasına bağlı olarak ülkemizde 2001'de başlanan hepatit B aşı programının sonuçlarının henüz ortaya çıkmamış olmasıyla açıklanabilir.

Çalışmamızın bir yönü de tarama yapılan hasta grubunun HBsAg, anti-HCV, anti-HIV ve VDRL açısından toplumun genel bir prevalansıyla karşılaştırma yapılabilmesine olanak tanımasıdır.

Toplumda görülen hepatit $\mathrm{B}$ ve $\mathrm{C}$ hastalığının, bu hastalıklar için koruyucu bir nitelik bulundurmayan, tam tersine riskli grubu oluşturan 109 hastalık bu seride sadece bir HBsAg ve bir anti-HCV pozitifliği ile düşük çıkması sürpriz olduğu kadar sevindiricidir. Hepatit B'ye sadece bir olguda rastlanmas1, taraması yapılan görece aktif genç yaş grubunun aşılanmasına bağlı olabilir. Son yapılan saha çalışmalarının birinde ülkemizde HBsAg pozitif bireylerin oran $1 \% 4$, anti-HBs pozitif oranın $\% 32$ olduğu, HBsAg pozitifliğinin yaşla arttığı ve bazı bölgelerde daha yüksek olduğu gösterilmiştir [5]. Otobüs projesi olarak adlandırılan bir çalışmada anti-HCV pozitif hasta oranı $\% 0,9$ olarak bulunmuştur [6]. Angiografi yapılan yaş ortalaması 61,5 yıl olan 415 hastanın seroprevalans çalışmasında HBsAg oranı $\% 2,2$, anti-HCV oranı ise $\% 0,2$ bulunmuş, anti-HIV pozitif vakaya rastlanmamıştır [7].

Hasta grubumuzun görece riskli grup olmasına karşın özellikle HBsAg oranlarının toplumda beklenenden düşük bulunması, esasında istatistik olarak genital siğillerin koruyucu tarafiyla açıklanıyor olması gerekir ama bu rasyonel değildir. 109 hasta değerlendirme için çok küçük bir sayıdır. Bu durum hasta grubunun yaş ortalamasının yaklaşık üçüncü dekadda olmasıyla da açıklanabilir. HBsAg pozitifliği yaşla artmaktadır [5]. Nitekim yaş ortalaması 33,7 olan hastalarımızla, Taş ve arkadaşlarının [7] yaş ortalaması 61,5 yıl olan hasta grubu arasındaki fark buna yorumlanabilir. Aşılama ve daha da önemlisi toplumsal duyarlılığın ve halk sağlığı önlemlerinin 
artması sözü geçen seksüel geçişli hastalıkların yayılmasını azaltmış olmalıdır diye düşünülebilir. $\mathrm{Bu}$ sonuca göre $\mathrm{HBsAg}$ pozitifliğinin düşük olması beklenen bir bölgede (Batı Karadeniz) yer almamız ve yaş ortalaması 33 yıl olan genç bir hasta grubunda inceleme yapmamız nedeniyle 109 hastanın sadece birinde HBsAg ve anti-HCV pozitifliğinin görülmesi çok şaşırtıcı olmayabilir. $\mathrm{Bu}$ durum hepatit $\mathrm{B}$ prevalansının son yıllarda doğu, güneydoğu bölgeleri ile kısmen İç Anadolu bölgesi dışında giderek azalmakta olduğunu gösteren çalışmalar ile uyumludur [5].

Çalışmanın kısıtlamaları çalışmanın sadece dermatoloji kliniğinde yapılmış olmasıdır. Kadın hastalıkları ve doğum kliniği de dahil edildiğinde cinsiyet oranları değişebilir.

Sonuç olarak, cinsel yolla bulaşabilen hepatit, AIDS, sifiliz gibi hastalıkların belirgin klinik bulgusunu taşımayan genital siğilli hastalarda, girişimsel bir tedaviye gereksinim duyulmadıç̧a tarama testlerinin istenmemesi çıkarımı yapılabilir. $\mathrm{Bu}$ çıkarım klinisyene zaman kazandırmasının yanında tıbbi maliyetin azaltılması gibi yararları olabileceği yorumunu çıkarmak mümkündür. Görece çok sayıda 40 yaş üstü erkek hasta olmasının da toplum sağlığı açısından değerlendirilmesi gereken bir durum olduğu düşüncesindeyiz.

\section{Kaynakça}

1. Stratton KL, Culkin DJ. A contemporary review of HPV and penile cancer. Oncology (Williston Park) 2016; 30: 245-9.

2. Unal E, Gonul M, Cakmak S, Yalcinkaya, İyidal A, Kılıc A, Gul U, Doner P. Serological test results of sexually transmitted diseases with condyloma acuminata. Postepy Dermatol Alergol 2015; 32: 286-9.

3. Kaymak Y, Yüksel N, Eksioglu M. Coincidence of condyloma accuminata with other sexually transmitted diseases. Turk Derm 2004; 38: 48-53.

4. Kavak A, Parlak A, Akman R, Yeşildal N, Anul H, Aydoğan İ, Çiçekçi B, Kaya D. An evaluation of hepatitis B, C and HIV infections in sexually transmitted diseases. Turk Derm 2002; 36: 272-5.

5. Tosun S. Viral hepatitlerin ülkemizdeki değişen epidemiyolojisi. ANKEM Derg 2013; 27: 128-34.

6. Balık İ, Tosun S, Tabak F, Saltoğlu N, Örmeci N, Şencan İ, Gürbüz Y, Öztoprak N. Ülkemizde gezici ekiple viral hepatit epidemiyolojisinin araştırılması (VHSD Otobüs Projesi), XI. Ulusal Viral Hepatit Kongresi, Antalya, Türkiye, 2012; s.44.

7. Taş T, Koçoğlu E, Küçükbayrak A, Mengeloğlu FZ, Erdem A, Erdem K, Bucak Ö. Anjiyografi yapilan hastalarda Hepatit B, Hepatit C ve HIV seroprevalans1. Abant Medical Journal 2013; 3: 224-6. 